\title{
Quantitative assessment of AOD from 17 CMIP5 models based on satellite-derived AOD over India
}

\author{
Amit Misra $^{1}$, Vijay P. Kanawade ${ }^{1, a}$, and Sachchida Nand Tripathi ${ }^{1,2}$ \\ ${ }^{1}$ Department of Civil Engineering, Indian Institute of Technology Kanpur, Kanpur, India \\ ${ }^{2}$ Centre for Environmental Science and Engineering, Indian Institute of Technology Kanpur, Kanpur, India \\ ${ }^{a}$ currently at: University Centre for Earth \& Space Sciences, University of Hyderabad, Hyderabad, India \\ Correspondence to: Amit Misra (sri.amit.misra@gmail.com) and Sachchida Nand Tripathi (snt@iitk.ac.in)
}

Received: 20 January 2016 - Revised: 16 June 2016 - Accepted: 9 July 2016 - Published: 3 August 2016

\begin{abstract}
Aerosol optical depth (AOD) values from 17 CMIP5 models are compared with Moderate Resolution Imaging Spectroradiometer (MODIS) and Multiangle Imaging Spectroradiometer (MISR) derived AODs over India. The objective is to identify the cases of successful AOD simulation by CMIP5 models, considering satellite-derived AOD as a benchmark. Six years of AOD data (2000-2005) from MISR and MODIS are processed to create quality-assured gridded AOD maps over India, which are compared with corresponding maps of 17 CMIP5 models at the same grid resolution. Intercomparison of model and satellite data shows that model-AOD is better correlated with MISR-derived AOD than MODIS. The correlation between model-AOD and MISR-AOD is used to segregate the models into three categories identifying their performance in simulating the AOD over India. Maps of correlation between model-AOD and MISR-/MODIS-AOD are generated to provide quantitative information about the intercomparison. The two sets of data are examined for different seasons and years to examine the seasonal and interannual variation in the correlation coefficients. Latitudinal and longitudinal variations in AOD as simulated by models are also examined and compared with corresponding variations observed by satellites.
\end{abstract}

Keywords. Atmospheric composition and structure (aerosols and particles)

\section{Introduction}

Knowledge of aerosol concentration, type, and physical and chemical properties is necessary to understand their role in Earth's climate system (Boucher et al., 2013). This infor- mation can be obtained from in situ measurements, satellite and ground-based remote sensing, and model simulations. In situ measurements are carried out either in campaign mode (ship-cruises, land campaign, or short-term observations of any event) or long-term observations over any monitoring site. Remote sensing provides means of long-term routine, unmonitored measurements of global aerosol concentration, with limited accuracy (King et al., 1999). Models provide aerosol concentration based on emission inventories as initial conditions, and simulate their evolution considering various changes in atmospheric conditions (Ghan and Schwartz, 2007).

Being point observations, in situ measurements cannot provide global coverage of aerosol properties. This can be obtained from satellite observation which, due to the large swath and near-polar orbits of satellites, can provide more frequent aerosol map throughout the globe (King et al., 1999). The retrieval of aerosol properties from satellitemeasured radiances involves several assumptions mainly pertaining to aerosol type and underlying surface features (Kaufman et al., 1997). The satellite-derived values are modelled results, and their accuracy is assessed with the help of ground-based observations (Chu et al., 2002; Liu et al., 2004; Kahn et al., 2005; Levy et al., 2010).

On the other hand, models also provide forecast on how the present aerosol climatology would evolve after a certain period of time. This helps in planning the mitigation measures to limit the effect of aerosols on climate and environment. The hindcast obtained by models aids in understanding the variation in aerosol properties over a long timescale extending to several years and decades (Ghan and Schwartz, 2007). 
However, in order to make use of these applications of model data in studying the aerosol properties in past and future, it is imperative to successfully model the existing aerosol scenario (Ghan and Schwartz, 2007). Any error in the initial conditions of the model run will affect the derived values. This level of accuracy can be assessed by comparing with satellite-derived values (Pan et al., 2015; Sanap et al., 2014; Ganguly et al., 2009). Note that the satellite-derived AOD values are themselves modelled results, and not the "truth" values per se against which the model data could be "validated". Still, as mentioned previously, the accuracy of satellite-derived values is assessed based on validation using ground-based observations. Hence, while comparing modelderived aerosol concentration with satellite-derived aerosol properties, we have a limit of accuracy up to which the two data sets can be expected to match. Model and satellite both provide global coverage, and it is logical to compare them on a global scale. However, such comparison requires detailed information about geographical and meteorological features throughout the world to explain the differences between the two data sets.

Hence, in the present work, we have focused our attention on the Indian subcontinent, and examined the performance of the models over India, where we have sufficient knowledge of geography and meteorology. Satellite-derived AOD has been extensively validated over different regions of India using ground-based observations (for example, Tripathi et al. (2005), Prasad and Singh (2007), Jethva et al. (2007a, b), Choudhry et al. (2012), Misra et al. (2008, 2014b) have validated different versions of the MODIS aerosol product). Hence, the accuracy of MODIS-derived AOD is understood over several, though not all, locations of India. In addition, aerosol properties have been studied over India using a variety of in situ and remote-sensing measurements (Sagar et al., 2004; Dey et al., 2005; Devara et al., 2005; Ganguly et al., 2006; Krishna Moorthy et al., 2007; Srivastava et al., 2008; Kuniyal et al., 2009; Kaskaoutis et al., 2009; Vinoj et al., 2009; Pathak et al., 2010; Niranjan et al., 2011; Kumar et al., 2012; Lodhi et al., 2013; Verma et al., 2014). The aerosol scenario over India, study of anthropogenic and natural aerosols (Verma et al., 2011; Ramachandran et al., 2012), identification of pollution hot-spots (Di Girolamo et al., 2004), and the evolution and increase and/or decrease of pollution levels (Krishna Moorthy et al., 2013) over different timescales have also been studied. Several studies have investigated the aerosol climatology and explained it on the basis of prevailing meteorological variables (for example, Ganguly et al. (2006)). Thus, we know what type of aerosol pattern must be expected from the model results. The effect of local meteorology, which explains the aerosol climatology encountered over a region, should also be reflected in the modelled results.

In this paper, we have examined 17 models within the framework of CMIP5 (Coupled Model Intercomparison Project Phase 5) (Taylor et al., 2012) to evaluate their relative efficiency in simulating the aerosol concentration over the In- dian subcontinent. The distinction of this work from previous studies such as Shindell et al. (2013) and Pan et al. (2015) is in the quantitative comparison of models with satellite data. In addition, a comparison of the spatial and temporal variation in aerosol properties from models and satellites are presented and discussed.

\section{Study region}

We have done the comparison of model-derived AOD with satellite-derived AOD over the whole Indian territory (5$\left.30^{\circ} \mathrm{N}, 68-95^{\circ} \mathrm{E}\right)$. This study region encompasses large heterogeneity in aerosol properties, meteorology, and geography.

The high-altitude mountains, Himalayas and Hindu-Kush, being snow-covered during most part of the year, have fewer data from satellites. Similarly, desert region in western Indian states of Rajasthan and Gujarat pose difficulty to satellite remote sensing of aerosols (Misra et al., 2008, 2014b) due to the high surface reflectance. Accuracy of satellitederived AOD is high over the Bay of Bengal and Arabian sea due to the dark background provided by the ocean surface (Tanré et al., 1997). There are mountains of low altitudes over the western and eastern coasts of India, which pose no difficulty to satellite remote sensing of aerosols over these regions. However, large variations in surface features and topography pose difficulty because proper account of pressure variation with altitude should be made. Land cover in most of India encompasses agricultural fields, which have high moisture content due to the large number of rivers, their tributaries, canals, and irrigation projects. The MODIS over-land algorithm (dark target) has high accuracy over such regions. Highest pollution levels are usually noted along the IndoGangetic Basin (IGB), which is also a region of high population density. This region is affected by dust storms during pre-monsoon season (Dey et al., 2004), and dense fog during winter (Tripathi et al., 2006; Tare et al., 2006; Das et al., 2008). North-east India is a mountainous region of the Himalayas and receives the highest amount of rainfall in the country. Central India is a plateau with variable land usage low-altitude mountains, agriculture and forest.

\section{Data sets used}

As mentioned in the previous sections, the accuracy of satellite-derived AODs are usually known, albeit over selected locations of the study region. In addition, in most of the cases, the retrieval error can be attributed to surface reflectance or improper aerosol model assumption. The validation of satellite-derived AOD using ground-based sunphotometer measurements should ideally result in linear correlation, with slope as 1 and intercept as 0 . Improper aerosol model and inadequate surface reflectance parameterisation lead to deviation of slope and intercept from their corre- 
sponding ideal values. This is usually the simplest case. There could be additional sources of error arising out of complex nature of atmospheric radiation processes. Their effect depends on the nature of terrain and aerosol climatology. For example, earlier simulation studies had identified that neglecting polarisation in radiative transfer calculations (Levy et al., 2004), and angular and seasonal variation of surface reflectance ratios (Gatebe et al., 2001; Remer et al., 2001) would have additional effect on the accuracy of AODs retrieved by MODIS. These parameters were accordingly incorporated in the subsequent versions of the MODIS algorithm. Besides, cloud contamination is the biggest source of error in satellite-based remote sensing of aerosols.

Terra MODIS Level 3 monthly averaged quality-assured data were used. This product uses the QA (quality assurance) weighted mean to obtain the monthly average values, with the constraint that the number of daily data in the month should be greater than 5. As this product is available separately for land and ocean, we have created a merged data set, by filling the over-ocean AOD values in the corresponding grid cells. Note that the global validation of MODIS-derived AOD has shown that the accuracy of over-ocean AOD is greater than over-land AOD. Though collection 6 of the Terra MODIS aerosol product has been released, at the time of writing this paper, the full data from collection 6 are not available. Hence, we have used collection 5.1 of the Terra MODIS aerosol product.

We have calculated the monthly averaged gridded MISR AOD from the level 2 swath data using similar constraint on the number of days in the month as used for MODIS Level 3 product. The satellite data sets (MODIS and MISR) and modelled simulations were brought to equivalent grid resolution of 2.48 longitude by 1.99 latitude. The CMIP5 modeled simulations are available at a different and much coarser grid resolution. In order to perform correlation studies between satellite data and model simulations, the grid resolution was made consistent with the highest grid resolution available from the model (e.g. NOAA-GFDL-ESM2M, Table 1). Data sets were re-gridded using a cubic convolution interpolation method in Interactive Data Language (IDL) version 7.0.

We have examined 17 models within the framework of CMIP5. The model names and the various forcings considered by them are given in Table 1, and their spatial resolutions and references are presented in Table 2. Nor-ESM1$M$ and Nor-ESM1-ME differ in that the latter includes an interactive biogeochemistry (Bentsen et al., 2013); CSIROBOM-ACCESS1.0 and CSIRO-BOM-ACCESS1.3 differ in the land and atmosphere components that these models consider (Bi et al., 2013); NASA-GISS-E2-H and NASA-GISSE2-R differ from each other in the ocean model (Schmidt et al., 2014); NOAA-GFDL-ESM2G and NOAA-GFDLESM2M differ in the ocean component (Dunne et al., 2012); MOHC-HadGEM2-ES considers all earth system components, whereas MOHC-HadGEM2-CC excludes gas phase tropospheric chemistry (Collins et al., 2011). The present study spans the duration 2000-2005 due to the availability of consistent satellite and model data during this period. In this study we have compared only the total columnar AOD from satellites and models.

\section{Methodology}

We have studied the annual and seasonal average AOD of the models mentioned in Table 1 vis-a-vis MODIS- and MISRderived AOD. Through this approach, we are able to examine the extent to which the various models are able to reproduce the aerosol climatology observed by the satellite during the study period. A correlation map was also obtained to quantitatively examine the relative performance of the models under diverse geographical and meteorological environments. In addition, we have classified the 17 models into three categories based on their correlation with MISR-derived AOD. The basis of classification is the correlation coefficient of the models with MISR-derived AOD because, as will be discussed in Sect. 5, the comparison of models is, in general, better against MISR as compared to MODIS. The three classes are $R^{2} \geq 0.4 ; 0.2 \leq R^{2}<0.4 ; R^{2}<0.2$, and represent the cases of very good, intermediate, and poor comparisons, respectively (Table 2). $R^{2}$ values correspond to the spatially averaged $R^{2}$ between the model-MISR correlations over each pixel. In order to arrive at these categories, we have divided the range of $R^{2}$ values obtained into three classes of nearly same values (viz., 0.2). However, this categorization has a limitation that the number of models in different categories are not the same. Two models show very good comparison $\left(R^{2} \geq 0.4\right), 12$ models show intermediate comparison $\left(0.2 \leq R^{2}<0.4\right)$, whereas three models show poor comparison $\left(R^{2}<0.2\right)$ with MISR-derived AOD (Table 2).

\section{Results and discussion}

Table 2 gives correlation coefficients of 17 CMIP5 models with MODIS- and MISR-derived AODs. These correlations were performed over the spatial domain of $5-30^{\circ} \mathrm{N}$ and $68-95^{\circ}$ E. Overall, model AODs are better correlated with MISR-derived AODs than MODIS. It can also be noted that whenever the correlation between model and satellite data is good, MISR has even better correlation. This is an important result for the studies comparing model-derived AOD with satellite observations as it shows that the correlation results are better when AOD data from MISR sensor are used for the intercomparison. Another noticeable feature is that differences in the correlations exist between the models. Among all the CMIP5 models considered, only IPSLCM5A-MR and CISRO-Mk3.6.0 had overall correlation with MISR greater than 0.4. IPSL-CM5A-MR showed the best correlation with both MISR $\left(R_{\text {model-MISR }}^{2}=0.47\right)$ and MODIS $\left(R_{\text {model-MODIS }}^{2}=0.4\right)$. It was followed by CISROMk3.6.0 which was found to be well-correlated with MISR 
Table 1. Summary of forcings considered by the various models examined in this study. Ant = anthropogenic forcing, Nat $=$ natural forcing, $\mathrm{SD}=$ anthropogenic sulphate aerosol (direct effect), $\mathrm{SI}=$ anthropogenic sulphate aerosol (indirect effect), $\mathrm{GHG}=$ well-mixed greenhouse gases, $\mathrm{SA}=\mathrm{SD}+\mathrm{SI}, \mathrm{SO}=$ stratospheric ozone, $\mathrm{TO}=$ tropospheric ozone, $\mathrm{Oz}=\mathrm{TO}+\mathrm{SO}, \mathrm{Sl}=$ solar irradiance, $\mathrm{LU}=$ land-use change, $\mathrm{Vl}=$ volcanic aerosol, $\mathrm{Ds}=\mathrm{Dust}, \mathrm{OC}=$ organic carbon, $\mathrm{BC}=$ black carbon, $\mathrm{MD}=$ mineral dust, $\mathrm{SS}=$ sea salt, $\mathrm{AA}=$ anthropogenic aerosols (CMIP5 data reference syntax document).

\begin{tabular}{|c|c|}
\hline CMIP5 Model & Forcings \\
\hline CSIRO-Mk3.6.0 & Ant, Nat (all forcings) \\
\hline IPSL-CM5A-MR & Nat,Ant,GHG,SA,Oz,LU,SS,Ds,BC,MD,OC,AA \\
\hline CSIRO-BOM-ACCESS1.0 & GHG, Oz, SA, Sl, Vl, BC, OC \\
\hline MIROC-MIROC5 & GHG, SA, Oz, LU, Sl, Vl, SS, Ds, BC, MD, OC \\
\hline MOHC-HadGEM2-CC & GHG, Oz, SA, LU, Sl, Vl, BC, OC \\
\hline MOHC-HadGEM2-ES & GHG, SA, Oz, LU, Sl, Vl, BC, OC \\
\hline MRI-CGCM3 & GHG, SA, Oz, LU, Sl, Vl, BC, OC \\
\hline NASA-GISS-E2-H & GHG, LU, Sl, Vl, BC, OC, SA, Oz \\
\hline NASA-GISS-E2-R & GHG, LU, Sl, Vl, BC, OC, SA, Oz \\
\hline NCC-NorESM1-M & GHG, SA, Oz, Sl, Vl, BC, OC \\
\hline NCC-NorESM1-ME & GHG, SA, Oz, Sl, Vl, BC, OC \\
\hline NOAA-GFDL-ESM2G & GHG,SD,Oz,LU,S1,V1,SS,BC,MD,OC \\
\hline NOAA-GFDL-ESM2M & GHG,SD,Oz,LU,S1,Vl,SS,BC,MD,OC \\
\hline NSF-DOE-NCAR-CESM1-CAM5 & Nat, Ant, GHG, SD, Oz, LU, Sl, Vl, SS, Ds, BC, OC, MD, AA \\
\hline MIROC-MIROC4h & GHG, SA, Oz, LU, Sl, Vl, SS, Ds, BC, MD, OC \\
\hline CSIRO-BOM-ACCESS1.3 & $\mathrm{GHG}, \mathrm{Oz}, \mathrm{SA}, \mathrm{Sl}, \mathrm{Vl}, \mathrm{BC}, \mathrm{OC}$ \\
\hline NOAA-GFDL-CM3 & GHG,SA,Oz,LU,S1,Vl,SS,BC,MD,OC \\
\hline
\end{tabular}

Table 2. The CMIP5 models examined in this study along with their grid resolutions. The correlation coefficients of the comparison of modelderived AOD with MODIS and MISR AODs are also given. The various models are segregated into three groups based on the performance of their correlation with MISR AOD. Details are given in the text.

\begin{tabular}{lrrrrl}
\hline CMIP5 Model & Longitude & Latitude & MISR vs. CMIP5 & MODIS vs. CMIP5 & Reference \\
\hline CSIRO-Mk3.6.0 & 1.87 & 1.85 & 0.41 & 0.26 & Rotstayn et al. (2010) \\
IPSL-CM5A-MR & 2.48 & 1.26 & 0.47 & 0.4 & Dufresne et al. (2013) \\
\hline CSIRO-BOM-ACCESS1.0 & 1.87 & 1.24 & 0.21 & 0.21 & Bi et al. (2013) \\
MIROC-MIROC5 & 1.40 & 1.39 & 0.3 & 0.3 & Watanabe et al. (2010) \\
MOHC-HadGEM2-CC & 1.87 & 1.24 & 0.32 & 0.27 & Collins et al. (2011) \\
MOHC-HadGEM2-ES & 1.87 & 1.24 & 0.32 & 0.25 & Collins et al. (2011) \\
MRI-CGCM3 & 1.12 & 1.11 & 0.28 & 0.28 & Yukimoto et al. (2012) \\
NASA-GISS-E2-H & 2.48 & 1.98 & 0.35 & 0.28 & Schmidt et al. (2014) \\
NASA-GISS-E2-R & 2.48 & 1.98 & 0.29 & 0.22 & Schmidt et al. (2014) \\
NCC-NorESM1-M & 2.48 & 1.88 & 0.31 & 0.27 & Bentsen et al. (2013) \\
NCC-NorESM1-ME & 2.48 & 1.88 & 0.3 & 0.27 & Iversen et al. (2013) \\
NOAA-GFDL-ESM2G & 2.48 & 1.99 & 0.35 & 0.19 & Dunne et al. (2012) \\
NOAA-GFDL-ESM2M & 2.48 & 1.99 & 0.37 & 0.19 & Dunne et al. (2012) \\
NSF-DOE-NCAR-CESM1-CAM5 & 1.25 & 0.94 & 0.3 & 0.36 & Meehl et al. (2013) \\
\hline MIROC-MIROC4h & 0.56 & 0.56 & 0.12 & 0.09 & Sakamoto et al. (2012) \\
CSIRO-BOM-ACCESS1.3 & 1.87 & 1.24 & 0.08 & 0.09 & Bi et al. (2013) \\
NOAA-GFDL-CM3 & 2.48 & 1.98 & 0.14 & 0.08 & Donner et al. (2011) \\
\hline
\end{tabular}


$\left(R_{\text {model-MISR }}^{2}=0.41\right)$, but not with MODIS $\left(R_{\text {model-MODIS }}^{2}=\right.$ $0.26)$.

Figure 1 shows the AOD climatology over India derived by averaging the AOD data for the period 2000-2005. In this way, AOD maps from MODIS, MISR, and the CMIP5 model defined groups are obtained. The AOD climatology from CMIP5 models is averaged according to the three categories described previously. Note that differences exist between MISR and MODIS derived AOD also. This is mainly due to the different procedures followed by the two sensors for retrieval of AOD (Prasad and Singh, 2007; Cheng et al., 2012; Wong et al., 2013).

The spatial distribution of aerosols and demarcation of regions with particular value of AOD is more explicit in MISR-derived AOD maps than in MODIS where it is more chaotic. Thus, in MISR-derived AOD map, peninsular India has lower AOD $(<0.25)$, with AOD over Maharastra even lower $(\sim 0.15)$ than the states in the extreme south $(\sim 0.25)$. This is interesting, since several centres of high industrial activity like Mumbai, and developing centres of economic activity like Pune lie in this region. AOD over north-west India, and Pakistan is high ( $>0.55)$. This region is the Thar desert, and the dust aerosols result in the highest AOD among the whole study domain. IGB also shows AOD comparable $(>0.5)$ to that over Thar desert. IGB is prone to dust storms in pre-monsoon season (Dey et al., 2004) and extreme fog during winter (Tripathi et al., 2006; Tare et al., 2006). The dust encountered in this region can be locally generated, or transported from neighbouring countries (Misra et al., 2014a). Far beyond the coastal regions, AOD gradually decreases on moving southwards, so that AOD over northern Indian Ocean is very low $(<0.15)$. However, AOD over coasts is large this is the case for both eastern and western coasts $(\sim 0.3)$. This is noteworthy especially over the western coast where high AOD is observed between the two regions of low AOD over Maharastra and Arabian Sea. The region to the north of the Himalayas has extremely low AOD $(<0.1)$ - the lowest among the whole study domain. This is due to the fact that the Himalayas presumably put a hindrance to northward movement of aerosols from the IGB. In general, these features are consistent with several studies conducted over the subcontinent for characterisation of aerosols from in situ measurements (refer to the papers cited in Sect. 1).

MODIS-derived AOD plot also shows very high AOD over Thar desert and IGB $(>0.6)$ - even higher than that shown by MISR. The AOD over southern India is seen to be lower than northern India. AOD over the north Indian Ocean is still lower $(<0.1)$ than other regions. Higher AOD along eastern and western coasts $(\sim 0.3)$ as compared to neighbouring continental and oceanic region is noticed in MODIS-derived AOD plot also. However, the distinct pattern of AOD distribution and explicit identification of different AOD regions that was discernible in MISR-derived AOD plot is not seen in MODIS-derived plot. Pixels of high and low AODs are seen in nearly all the regions. AOD over north-east India and north
Indian ocean are nearly similar from MODIS and MISR. Another noteworthy feature is the presence of a large amount of missing data in MODIS-derived plot, especially to the north of the Himalayas.

The explicit demarcation of regions of different AODs observed by MISR is reproduced well by group 1 models. Thus, we see very high AOD over north-west India and southern Pakistan (>0.5), which are the regions encompassing Thar desert. AOD over southern India is lower than northern India in group 1 models derived AOD maps also. However, AOD over peninsular India $(<0.25)$ is nearly uniformly distributed; and the lower AOD over Maharastra than extreme south, which was clear in MISR-derived map, is not observed in group 1 plot. AOD over IGB is high $(\sim 0.5)$, and over western IGB is comparable to Thar desert. However, higher AOD over central IGB as observed by MISR is not seen in AOD maps produced by group 1 models. Group 1 models also fail to reproduce the high AOD along coasts which is conspicuous in both MISR and MODIS derived maps. Gradual decrease of AOD while moving away from coasts, and low AOD over north Indian Ocean is well simulated by group 1 models. Besides, extremely low AODs to the north of the Himalayas $(<0.1)$ are also seen.

Group 2 and group 3 models fail to reproduce most of the features observed in MISR or MODIS plots, and simulated by group 1 models. However, extremely low AOD $(<0.1)$ over the north Indian Ocean and Himalayan region are well simulated by group 2 and 3 models also. The only additional feature that is successfully simulated by group 2 and 3 models is the high AOD over the IGB (0.3-0.4). However, the higher AOD over central IGB observed in MISR-derived AOD map is not seen in group 2 or group 3 simulations. In fact, group 3 shows higher AOD over the eastern IGB (0.30.5 ) which implies an exactly opposite variation over IGB than that observed by MODIS and MISR. An interesting feature is the region of high AOD over the India-Bangladesh border which is simulated extremely well by group 3 models, and is also observed in MODIS-derived AOD map.

Figure 2 shows the maps of correlation of the three model groups with MODIS and MISR separately. Such correlation maps provide a quantitative perspective to the intercomparison, and help in identifying regions and cases of very good or bad comparisons, and the degree of good or poor correlation. Figure 2 also shows the correlation map between MODIS and MISR derived AODs for comparison. Regional dependence of correlation is observed in these maps.

The best correlation of group 1 models with MODIS as well as MISR is seen over Thar desert, north Arabian Sea, and Pakistan $\left(R_{\text {group1-MISR }}^{2} \sim 0.8 ; R_{\text {group1-MODIS }}^{2} \sim 0.7\right)$. In MISR-group 1 model comparison, the correlation is also good over north Bay of Bengal $\left(R^{2} \sim 0.6\right)$, and the region to the north of the Himalayas. Worst correlation is observed over north Indian Ocean $\left(R^{2}<0.2\right)$ and eastern coast. Similar correlation is seen for group 2 models also. The best correlation is maintained over north Arabian Sea, Thar desert, 

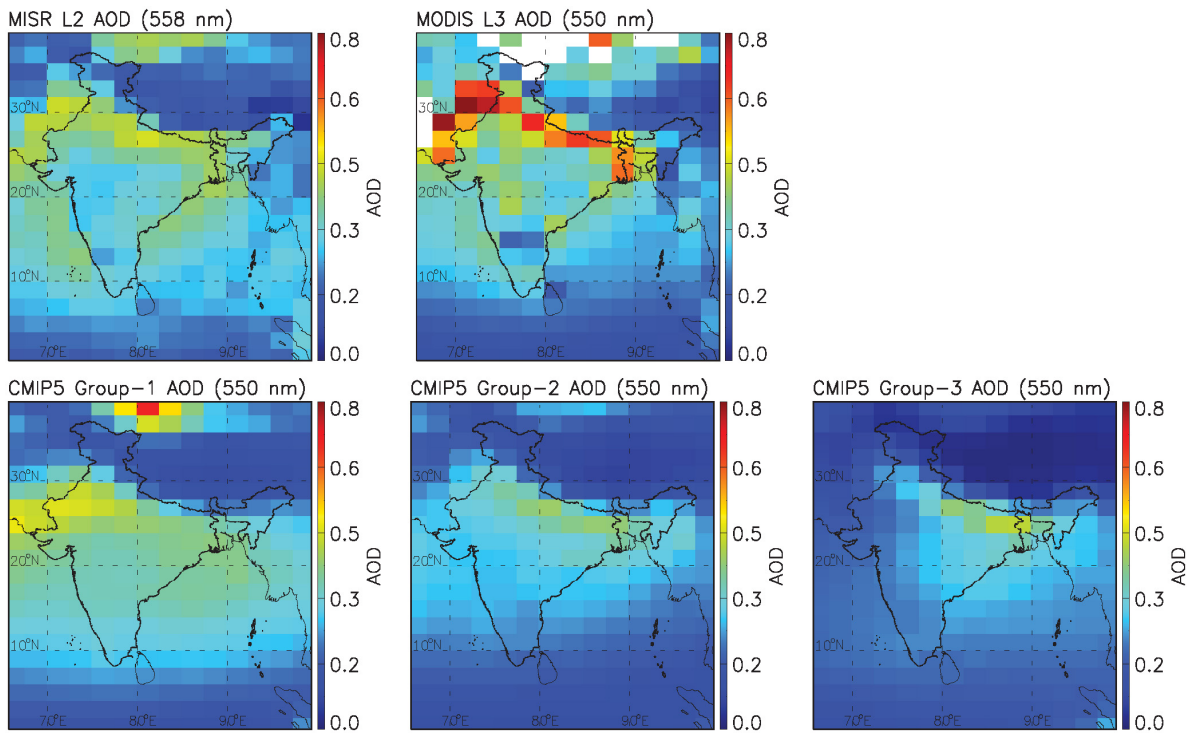

Figure 1. AOD climatology for 2000-2005 derived from MISR, MODIS, and the three model groups defined in the text.
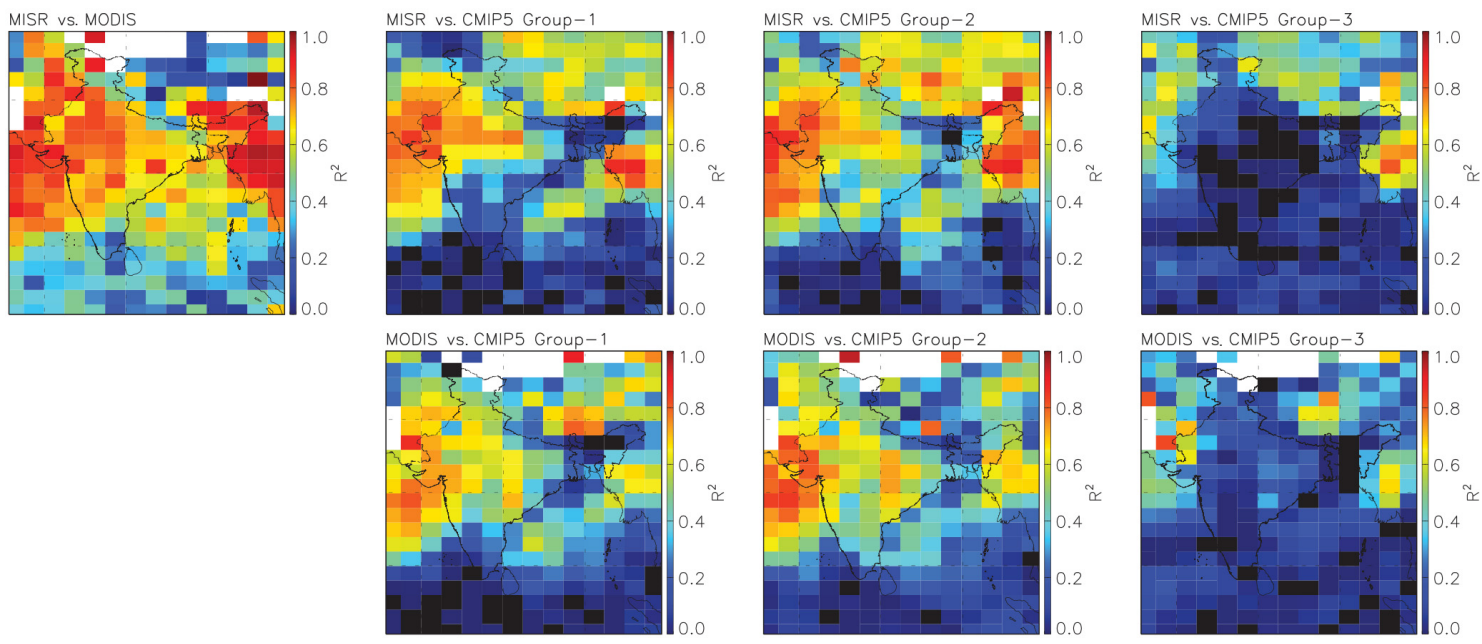

Figure 2. Spatial correlation map (2000-2005) for three model groups defined in the text with MISR and MODIS. The map of correlation between MISR and MODIS derived AODs is also shown.

and Pakistan. This is followed by north Bay of Bengal, and region to the north of the Himalayas. The north Indian Ocean and eastern coast have poor correlation in the case of group 2 models also. It is noted that the spatial extent of good correlation has increased in the case of group 2 models as compared to group 1 models. Further, over the northern Arabian Sea, the fraction of good correlation has increased in the case of group 2 models. Similar correlation pattern is observed with MISR as well as MODIS. The satellite-model correlation in the case of group 3 models is poor over the whole subcontinent. Only over the region to the north of the Himalayas, MISR-group 3 correlation is $\sim 0.6$.

It is interesting to note that, in spite of different retrieval procedures, MODIS and MISR have very good correlation over the landmass of the subcontinent. The correlation coefficient is $\sim 0.6$ over eastern India and along east coast. Over the north Arabian Sea, north Maharastra, Madhya Pradesh, Rajasthan, western IGB, north-east India, $R^{2}$ reaches as high as $\sim 0.8$; and over north Bay of Bengal upto $\sim 0.7$. Only over the north Indian Ocean and Tibet, MODIS-MISR correlation is poor with $R^{2}<0.4$. Over Thar desert, the good correlations between MISR/MODIS and model-derived AODs for groups 1 and 2 indicate a proper characterization of dust in these models; whereas the poor correlation for group 3 models implies an improper input related to dust aerosols.

Figure 3 shows that the anomaly (difference between satellite and model derived AOD) for group 1 models with respect to MISR is positive over Arabian Sea, north Indian Ocean, 


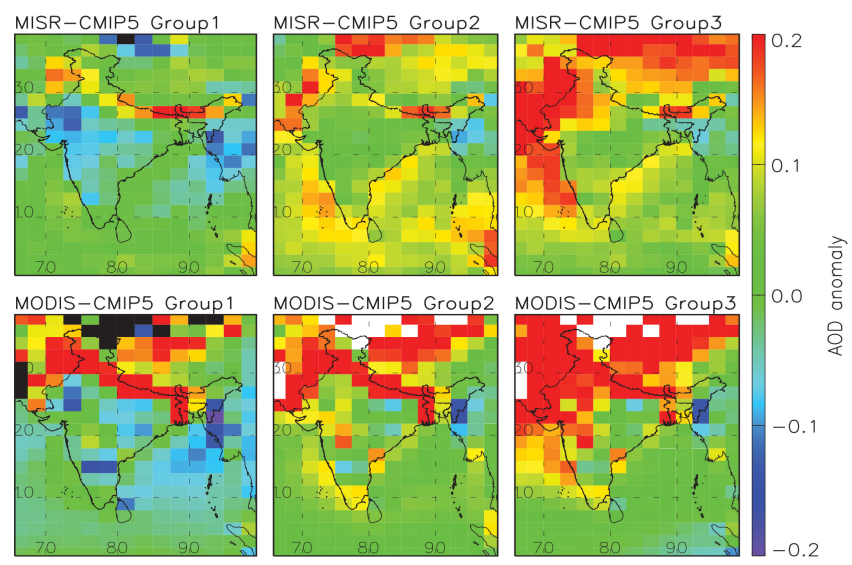

Figure 3. Anomaly in AOD climatology for 2000-2005 from MISR and MODIS, for the three model groups defined in the text.

and the Himalayan region, implying $\mathrm{AOD}_{\mathrm{MISR}}>\mathrm{AOD}_{\text {model }}$. Over the rest of the landmass, i.e., peninsular India, central India, and western India, anomaly is negative $\left(\right.$ AOD $_{\mathrm{MISR}}<$ $\left.\mathrm{AOD}_{\text {model }}\right)$. This is different in the case of MODIS where anomaly is negative over the Arabian Sea, Bay of Bengal, and north Indian Ocean also. The only regions of positive anomaly, i.e., where $\mathrm{AOD}_{\mathrm{MODIS}}>\mathrm{AOD}$ model are over the Himalayas, and a few patches in western India. In the case of group 2 and 3 models, the anomaly for both MODIS as well as MISR is positive implying underpredicted model-derived AOD. The underprediction is large (0.1) along the coasts. In the case of group 3 models, the simulated AOD is less by more than 0.15 over north-west India due to their failure in simulating the AOD climatology over Thar desert.

Figure 4 shows the seasonal variation in the aerosol climatology derived by MISR, MODIS, and the three model categories. The highest AOD over the whole subcontinent is encountered during monsoon (June, July, August). However, during this season, the satellite-derived AOD has a higher likelihood of cloud contamination as compared to other seasons. As we have put a condition on the minimum number of days for computing monthly average AOD, this implies fewer data during monsoon than other seasons. Similar condition arises during winter (December, January, February) when MODIS has difficulty retrieving AOD over snowcovered areas in the north of the Himalayas resulting in a scarcity of data over that region.

Seasonal variation is noted in AOD over different regions in the MISR-derived AOD maps. However, the pattern and magnitude of the change in AOD is region-specific. In the study region, AOD over eastern IGB and Bangladesh is highest during winter $(\sim 0.4)$ and pre-monsoon $(\sim 0.5)$, and minimum during post-monsoon $(\sim 0.25)$. During both these seasons, the AOD over this region is the highest among all regions of the whole subcontinent. AOD over Thar desert is highest during monsoon $(\sim 0.8)$, and is also high during premonsoon $(\sim 0.4)-$ second only to eastern IGB. This is inter- esting, since being dominated by desert dust aerosols, much less variation in AOD with relative humidity would be expected over this region. AOD over the north Indian Ocean is comparatively stable with much less variation in its value with seasons. However, large variation in AOD are noted over Arabian Sea and the Bay of Bengal. The AOD values over these regions are maximum during monsoon, followed by pre-monsoon.

Seasonal variation in AOD is observed in MODIS-derived plots also. However, as noted previously, the distinction of different AOD regions is not explicit in MODIS maps. Nevertheless, the seasonal variation in AOD over the subcontinent observed by MISR is corroborated by MODIS. AOD is highest during monsoon, followed by pre-monsoon. During post-monsoon and winter, AOD over the subcontinent is very low $(<0.25)$, with high AOD located only over IGB and southern Pakistan, due to hazy conditions prevailing during these seasons.

CMIP5 models in group 1 are comparatively more successful in reproducing the seasonal variation in AOD as compared to group 2 and 3 models. The extremely high AOD during monsoon season over the whole subcontinent, and high AOD over western India during pre-monsoon and monsoon seasons, is well reproduced. The lower AOD over southern India than northern India, especially during pre-monsoon, monsoon, and winter, is also reproduced. However, the models fail to reproduce the high AOD over eastern IGB. Besides, as noted previously, there is heterogeneity in aerosol concentration over peninsular India as observed by MISR. Thus, AOD over Maharastra is lower than regions further towards the south, especially during pre-monsoon and post-monsoon. Though this heterogeneity is reproduced by group 1 models during post-monsoon, these models show nearly uniform aerosol concentration over peninsular India during premonsoon. AOD over the Arabian Sea, Bay of Bengal, and north Indian Ocean is well simulated by group 1 models, and the seasonal variation is similar to that shown in MODIS and MISR maps especially during winter, monsoon, and postmonsoon seasons. High AOD along the eastern and western coasts are observed in MISR and MODIS maps, which are not simulated by group 1 models.

Performance of group 2 and group 3 models is very poor as compared to group 1 models. The magnitude of simulated AOD during all seasons is much lower than satellite and group 1 models. Group 2 models are able to show the regions of high AOD. Thus, high AOD over western India during monsoon, and higher AOD over IGB during all seasons is discernible in group 2 plots. On the other hand, group 3 models completely fail in simulating the high AOD over western India, especially over Thar desert which is so conspicuous in all other data sets. This implies an inadequate provision of desert dust aerosol in group 3 models. The group 3 consists of three models: CSIRO-BOM-ACCESS1.3, NOAA-GFDLCM3, and MIROC-MIROC4h. CSIRO-BOM-ACCESS 1.3 does not consider dust aerosols in their simulations (Bi et al., 

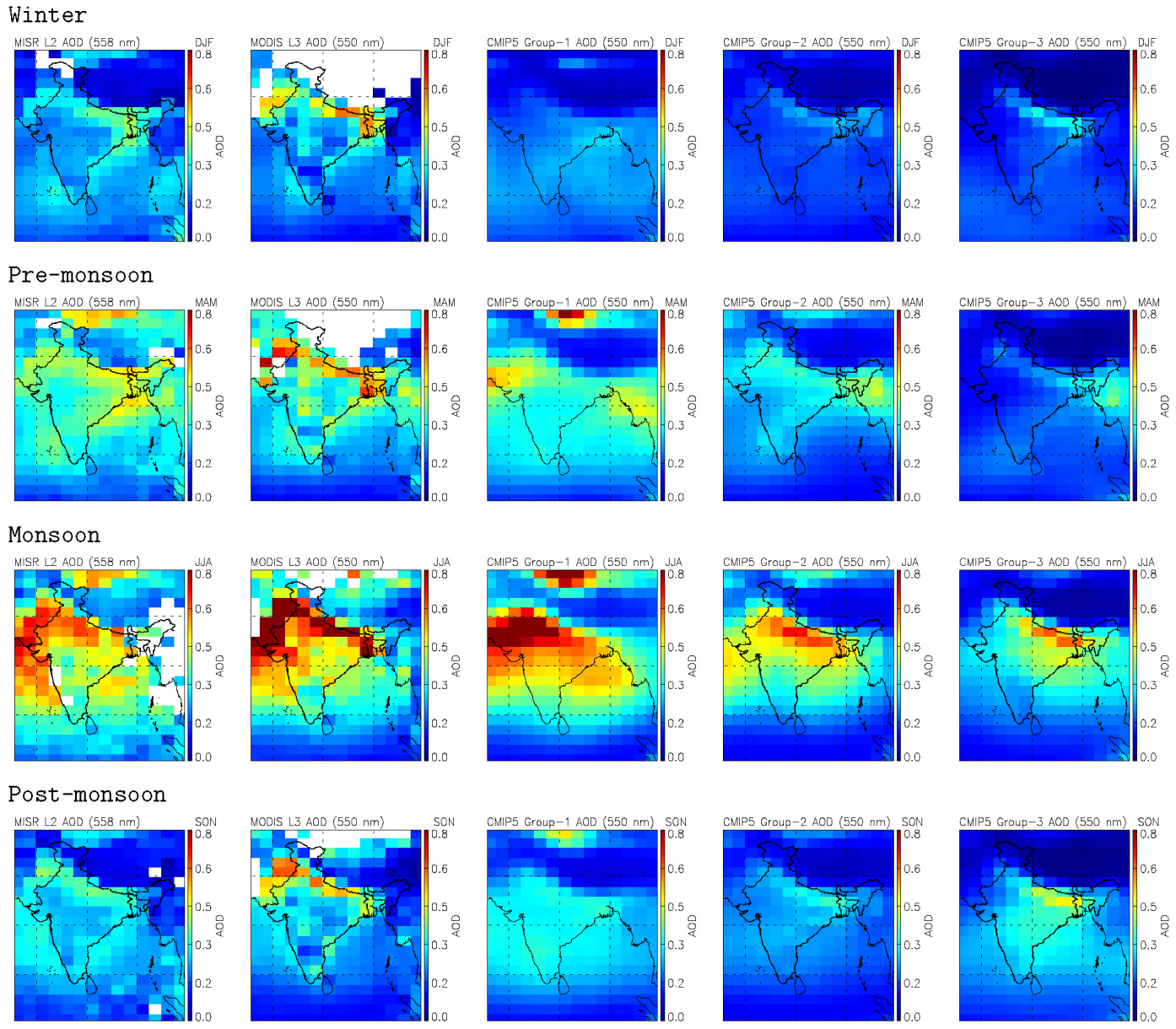

Figure 4. Seasonal variation of AOD for 2000-2005 derived from MISR, MODIS, and the three model groups defined in the text. The seasons have been defined as monsoon (June, July, August), post-monsoon (September, October, November), winter (December, January, February), and pre-monsoon (March, April, May).

2013). In fact, the underlying atmospheric physics has not yet been thoroughly tested in the CSIRO-BOM-ACCESS 1.3 model (Bi et al., 2013). Dust emissions in the NOAA-GFDLCM3 model are based on the parameterization given by Ginoux et al. (2001). However, in a recent study, Kumar et al. (2014) found Ginoux et al. (2001) parameterization to underestimate the dust emissions over Thar desert (R. Kumar, personal communication, 2016). Hence Kumar et al. (2014) in their study readjusted the dust emissions using AERONET observations. Thus, for both CSIRO-BOM-ACCESS1.3 and NOAA-GFDL-CM3, the poor simulation of AOD is due to inadequate dust characterization in these models. Besides, there is a variation in soil type in the north Indian region, leading to difference in dust flux observed over various locations (Desouza et al., 2015). Improvement of the dust emission used in the model simulations based on groundbased measurements would lead to better estimates of AOD. The cause of poor performance of MIROC-MIROC4h could not be ascertained. Although this model does consider dust aerosols in the simulations, the accuracy of dust emissions is not clear (T. Sakamoto, personal communication, 2016). There is a possibility of some bias because of surface wind and surface condition, but these factors have not been examined systematically (T. Sakamoto, personal communication, 2016). To examine the performance of this model over different regions, we examined its correlation with MISR derived AOD over different regions of India. The various values of the correlation coefficient are as follows - all data: 0.12, Thar desert: 0.40, central India: 0.005, southern India: 0.03; IGB: 0.10; Arabian sea: 0.003, Bay of Bengal: 0.02. Thus, we notice that MIROC4h model has the best correlation over Thar desert, and its overall poor correlation is due to its inferior performance over all other regions. Nevertheless, the ability of group 3 models is superior to group 1 and group 2 models in simulating high AOD over eastern IGB during winter and post-monsoon seasons.

Figure 5a shows the time series of AOD from MODIS, MISR, and the three groups of CMIP5 models. The respec- 


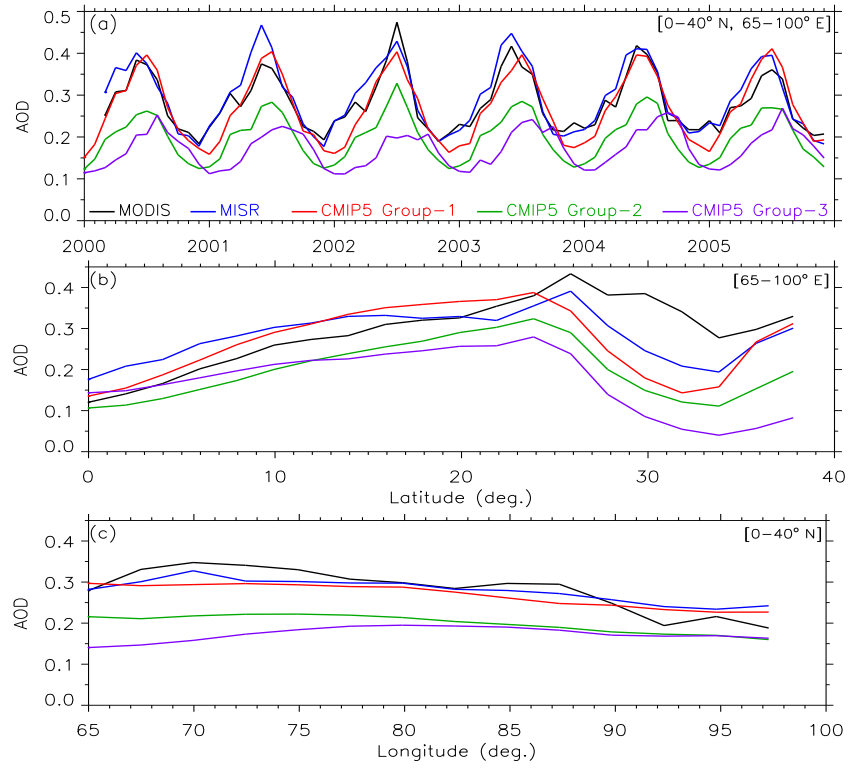

Figure 5. (a) Time series of AOD for 2000-2005 derived from MISR, MODIS, and the three model groups defined in the text. (b) Variation of AOD from different data sets with latitude. (c) Variation of AOD from different data sets with longitude.

tive AODs are obtained by averaging over the Indian domain. The average AODs for the three CMIP5 model groups are obtained by further averaging over the corresponding models. There is a known seasonal variation of AOD over different locations of the Indian subcontinent as reported by Mehta (2015). Using 13 years (2001-2013) data from MODIS and MISR sensors, Mehta (2015) has studied the spatial and temporal variation in AOD over the Indian territory. Maximum aerosol content over the country is observed during monsoon season, mainly due to wind and relative humidity (Mehta, 2015). Lowest aerosol content is observed during winter season. Besides, different parts of India have different processes leading to high aerosol content during particular seasons. Over northern India, agricultural waste burning leads to high aerosol content during post monsoon. Over west India, longrange transport leads to high AOD during monsoon season. The peculiar topography and meteorology, in addition to anthropogenic emission, aid in building up high aerosol concentration over east India. Comparatively lower values of AOD are observed over southern India (Mehta, 2015).

From Fig. 5a, we see that the seasonal variation in AOD is reproduced by all the three model groups. The magnitude of AOD is well reproduced by group 1 models; however, it is very low for group 2 and 3 models. A perfect match in AOD observed by group 1 models, MISR, and MODIS is noted during 2001 and 2004. During post-monsoon and early winter, when AODs are low, MODIS and MISR derived AODs compare well. There is negligible difference during "decreasing AOD" months of August to December, which include the post-monsoon season. The differences exist for January to May months. An increase in minimum AOD and a decrease in maximum AOD is observed in MODIS and MISR data during 2002-2005. However, such changes are not reflected in group 1 model data. The differences in AOD from different data sets are seen to exist mostly in the January to May period (Fig. 5a).

Figure $5 b$ shows the variation of AOD with latitude for MODIS, MISR, and the three model groups. Some interesting features can be noted from this figure. The peculiar variation of AOD vs. latitude is characteristic of this region. There is a remarkable variation in AOD with latitude - it increases upto the Himalayan foothills $\left(\sim 27^{\circ} \mathrm{N}\right)$, then drops sharply (till $\sim 34^{\circ} \mathrm{N}$ ), and slowly increases again. This feature is marked in AOD data from both MISR and MODIS, and is reproduced by all models with varying degrees. The slow increase in AOD from the equator to the Himalayan foothills could be due to the fact that in this latitude range, the ocean area continuously decreases with latitude in the domain considered, so that for lower latitudes, there is more contribution from oceans whereas for higher latitudes there is higher contribution from land mass. The latter is more polluted due to the dominance of anthropogenic aerosols resulting from the high population density. Gautam et al. (2010) found high AOD over northern Arabian Sea during May-June as compared to April, which was attributed to long-range transport of dust aerosols. Latitudinal gradient in aerosol radiative forcing was also found by Satheesh et al. (2010). The region in the domain that falls to the north of the Himalayas can be considered to be pristine as very less anthropogenic activity takes place in that region.

The AOD values from group 2 and group 3 models are lower than AOD from group 1 models, MODIS, and MISR, for all latitude values. However, the AOD from group 1 models is comparable to those from MODIS and MISR, with over/under-estimation for a distinct latitude range. For 0 $12^{\circ} \mathrm{N}$, MISR derived AOD is observed to be higher than group 1 model AOD, whereas for $12-25^{\circ} \mathrm{N}$, group 1 is higher than MISR-AOD. Beyond $25^{\circ} \mathrm{N}$, MISR derived AOD is again higher than group $1 \mathrm{AOD}$. One possible reason could be the presence of ocean in the $0-25^{\circ} \mathrm{N}$ latitude range. The separation can be interpreted in terms of land vs. ocean; or highly polluted vs. comparatively cleaner environments (e.g., oceans, southern tip of India, Himalayas and northern India). Largest variation in AOD is shown by MODIS, its values are lower than those from MISR for $0-18^{\circ} \mathrm{N}$, and higher beyond; lower than group 1 models for $0-24^{\circ} \mathrm{N}$ and higher beyond. AOD magnitude from MODIS over $26-35^{\circ} \mathrm{N}$ is very large as compared to MISR and group 1 models. Fewer data from MODIS are available from the region to the north of $30^{\circ} \mathrm{N}$ due to snow-covered Himalayan region, where MODIS has limitation with aerosol retrieval. In summary, the variation in AOD with latitude is reproduced well by all three categories, though there are numerical differences, which get larger over the north of IGB. Dumka et al. (2014) have re- 
cently shown the latitudinal variation in aerosol properties over the IGB based on ground-based remote-sensing data from AERONET. They observed an increase in AOD from the central Himalayas to IGB.

Figure $5 \mathrm{c}$ shows the variation of AOD with longitude. AOD from MISR and group 1 models match perfectly well for $72-82^{\circ} \mathrm{E}$. For longitude $<72^{\circ} \mathrm{E}$, and longitude $>82^{\circ} \mathrm{E}$, MISR-derived AOD is marginally high. A kink is observed at exactly $70^{\circ}$ E. A decrease of about 0.1 in AOD is observed with longitude; not all models are able to reproduce this variation. Only group 1 reproduces the slightly decreasing trend in AOD with longitude. Variation in AOD simulated by group 2 and group 3 models is similar for longitudes to the east of $83^{\circ} \mathrm{E}$. These are the longitudes dominated by oceans (Bay of Bengal) and pristine hills of Himalayan range. This shows that the performance of the models in group 2 and group 3 is same under such geographical conditions. However, for western India, with high AOD, the variation in AOD observed by these categories is different. This is most probably due to the provision of dust aerosols in the group 2 and group 3 models. The variation of AOD with longitude is similar to the amount of dust aerosol present, i.e. the area of dust dominated region. However, both group 2 and group 3 models have very low AOD as compared to MODIS, MISR, and group 1 models.

MODIS-derived AOD are very high in the $66-76^{\circ} \mathrm{E}$ region, which encompasses the Thar desert dominated by desert dust aerosols. Regions to the east of $87^{\circ} \mathrm{E}$ have comparatively low AOD. These are the regions receiving higher rainfall. Contribution from oceans is also largest in this longitude range. Whatever land mass is present in the domain corresponding to this longitude range, is dominated by mountainous region, which are comparatively pristine. However, Gogoi et al. (2011) have shown that the aerosol properties at Dibrugarh in north-east India are affected by the aerosol climatology in the IGB. Gogoi et al. (2011) had observed AOD at Dibrugarh to vary between $0.21 \pm 0.03$ in October and $0.63 \pm 0.09$ in March. Pathak et al. (2010) have shown that the BC concentration at Dibrugarh is lower than Kanpur in central IGB, but is comparable to that over other locations in India. A sharp decrease in MODIS AOD is observed to the east of $87^{\circ} \mathrm{E}$, which is not observed in other data sets (Fig. 5c). MODIS-derived AOD are similar to those from MISR and group 1 models in the longitude range $77-83^{\circ} \mathrm{E}$. A slight increase is observed in MODIS-derived AOD between 83 and $87^{\circ}$ E. Srivastava et al. (2011) had found AOD at Gandhi College in eastern IGB to be higher than at Kanpur in central IGB during pre-monsoon season. They infer a positive gradient in AOD over the region. Thus, the longitudinal variation in AOD observed by satellites and simulated by models (Fig. 5c) is consistent with ground-based observations. The role of low AOD over the Arabian Sea and Bay of Bengal in producing the latitudinal and longitudinal variation in AOD observed in our study is corroborated by the studies of Vinoj et al. (2008) and Naseema Beegum et al. (2012). Vi-

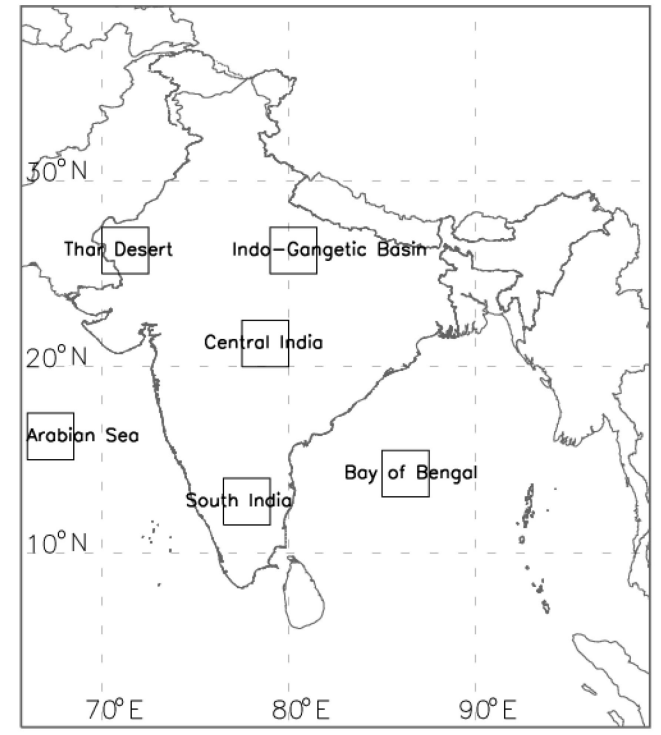

Figure 6. The various sub-regions in the study area over which 8 selected models were examined in further detail.

noj et al. (2008) had observed AOD at Minicoy in southern Arabian Sea to vary between 0.15 and 0.5. Naseema Beegum et al. (2012) found AOD between 0.15 and 0.4 over Port Blair in the Bay of Bengal. Note that the AOD values obtained by Vinoj et al. (2008) and Naseema Beegum et al. (2012) correspond to southern remote Arabian Sea (Minicoy) and eastern BoB (Port Blair), respectively.

In order to further explore the model-satellite comparison, we examined the correlation coefficients of some of the models: IPSL-CM5A-MR (Dufresne et al., 2013), CSIRO-BOM-ACCESS1.0 (Bi et al., 2013), NOAA-GFDLESM2M, NOAA-GFDL-ESM2G (Dunne et al., 2012), MIROC-MIROC5 (Watanabe et al., 2010), MRI-CGCM3 (Yukimoto et al., 2012), NCC-NorESM1-M (Bentsen et al., 2013), NCC-NorESM1-ME (Tjiputra et al., 2013) over selected regions (Fig. 6). The regions considered are the following: Thar desert $\left(25^{\circ} \mathrm{N}, 70^{\circ} \mathrm{E}\right)$ to $\left(27.5^{\circ} \mathrm{N}, 72.5^{\circ} \mathrm{E}\right)$, central India $\left(20^{\circ} \mathrm{N}, 77.5^{\circ} \mathrm{E}\right)$ to $\left(22.5^{\circ} \mathrm{N}, 80^{\circ} \mathrm{E}\right)$, southern India $\left(11.5^{\circ} \mathrm{N}, 76.5^{\circ} \mathrm{E}\right)$ to $\left(14^{\circ} \mathrm{N}, 79^{\circ} \mathrm{E}\right)$, Indo-Gangetic Basin $\left(25^{\circ} \mathrm{N}, 79^{\circ} \mathrm{E}\right)$ to $\left(27.5^{\circ} \mathrm{N}, 81.5^{\circ} \mathrm{E}\right)$, Arabian Sea $\left(15^{\circ} \mathrm{N}\right.$, $\left.65^{\circ} \mathrm{E}\right)$ to $\left(17.5^{\circ} \mathrm{N}, 67.5^{\circ} \mathrm{E}\right)$, the Bay of Bengal $\left(13^{\circ} \mathrm{N}, 85^{\circ} \mathrm{E}\right)$ to $\left(15.5^{\circ} \mathrm{N}, 87.5^{\circ} \mathrm{E}\right)$ (Fig. 6).

Few interesting features are noted in the correlation coefficients with MISR (Table 3). IPSL-CM5A-MR has good correlation with MISR over all of India, and also over Thar desert, central India, IGB, Arabian Sea and the Bay of Bengal. Only over southern India the IPSL-MISR correlation is inferior (0.3).

Considering the specific regions, over Thar desert, except MIROC-MIROC5, all models have modest to good correlation (greater than 0.35). Over Arabian Sea, only MRICGCM3 and NCC-NorESM1 (both versions) have poor cor- 
Table 3. Summary of correlation results over the sub-regions depicted in Fig. 6.

\begin{tabular}{|c|c|c|c|c|c|c|c|c|c|c|c|c|c|c|}
\hline & \multicolumn{2}{|c|}{ India } & \multicolumn{2}{|c|}{ Thar } & \multicolumn{2}{|c|}{ Central India } & \multicolumn{2}{|c|}{ Southern India } & \multicolumn{2}{|c|}{ IGB } & \multicolumn{2}{|c|}{ Arabian Sea } & \multicolumn{2}{|c|}{$\mathrm{BoB}$} \\
\hline & MODIS & MISR & MODIS & MISR & MODIS & MISR & MODIS & MISR & MODIS & MISR & MODIS & MISR & MODIS & MISR \\
\hline MISR & 0.61 & 1.0 & 0.88 & 1.0 & 0.68 & 1.0 & 0.51 & 1.0 & 0.68 & 1.0 & 0.81 & 1.0 & 0.52 & 1.0 \\
\hline IPSL-CM5A-MR & 0.40 & 0.45 & 0.63 & 0.69 & 0.42 & 0.61 & 0.45 & 0.30 & 0.30 & 0.63 & 0.76 & 0.76 & 0.46 & 0.58 \\
\hline CSIRO-BOM-ACCESS1.0 & 0.21 & 0.21 & 0.42 & 0.45 & 0.51 & 0.05 & 0.22 & 0.02 & 0.02 & 0.01 & 0.67 & 0.57 & 0.12 & 0.11 \\
\hline NOAA-GFDL-ESM2M & 0.21 & 0.37 & 0.55 & 0.68 & 0.25 & 0.18 & 0.09 & 0.14 & 0.13 & 0.35 & 0.77 & 0.76 & 0.06 & 0.06 \\
\hline NOAA-GFDL-ESM2G & 0.21 & 0.35 & 0.60 & 0.71 & 0.18 & 0.11 & 0.02 & 0.02 & 0.17 & 0.31 & 0.80 & 0.78 & 0.004 & 0.02 \\
\hline MIROC-MIROC5 & 0.29 & 0.29 & 0.05 & 0.22 & 0.14 & 0.51 & 0.06 & 0.15 & 0.25 & 0.26 & 0.64 & 0.75 & 0.29 & 0.15 \\
\hline MRI-CGCM3 & 0.28 & 0.30 & 0.19 & 0.35 & 0.42 & 0.44 & 0.17 & 0.10 & 0.14 & 0.15 & 0.28 & 0.26 & 0.21 & 0.33 \\
\hline NCC-NorESM1-M & 0.27 & 0.31 & 0.11 & 0.38 & 0.08 & 0.29 & 0.14 & 0.21 & 0.25 & 0.27 & 0.31 & 0.18 & 0.004 & 0.001 \\
\hline NCC-NorESM1-ME & 0.27 & 0.30 & 0.38 & 0.51 & 0.07 & 0.35 & 0.17 & 0.41 & 0.16 & 0.42 & 0.22 & 0.30 & 0.008 & 0.02 \\
\hline
\end{tabular}

relation. Thus, over these two regions the performance of various models is good. It should be noted that these two regions are affected by desert dust presence and transport.

Over IGB and southern India, only IPSL-CM5A-MR and NCC-NorESM1-ME have good and moderate correlation, respectively. Over the Bay of Bengal, performance of all models, except IPSL-CM5A-MR, is poor.

The better performance of NCC-NorESM1-ME over NCC-NorESM1-M model based on correlation with MISRderived AOD is observed over different regions - Thar desert, central India, southern India, IGB Arabian Sea, the Bay of Bengal. These two models are the same in all aspects other than the inclusion of biogeochemical cycle, particularly the carbon cycle in the model NorESM1-ME. Though some tuning was also done in NorESM1-ME for low-level cloud parameterization (J. Tjiputra, personal communication, 2016), in our study we did not find any significant difference between the low-level cloud concentration from these two models. Hence, the biogeochemical cycle is the most probable cause for the better performance of NorESM1-ME model. Further detailed study is required to ascertain how including an interactive carbon cycle improves the simulation of atmospheric aerosols by models.

Similarly, in the two versions of the NOAA-GFDL model, viz., NOAA-GFDL-ESM2M and NOAA-GFDL-ESM2G, the former uses Modular Ocean Model V4.1 with vertical pressure layers, whereas the latter uses generalized ocean layer dynamics with a bulk mixed layer and interior isopycnal layers. The correlation coefficient of these models with MISR over all of India is similar and also nearly similar over the different regions considered, except over southern India. One could argue that, as the aerosol climatology over southern India is influenced by oceans to a great extent, need of a proper account of ocean properties is understandable. However, we do not observe such differences over the Bay of Bengal and the Arabian Sea.

\section{Conclusions}

We have performed quantitative evaluation of 17 CMIP5 models using MISR and MODIS derived AOD. Overall, the models correlate better with MISR-derived AOD as compared to MODIS-derived AOD. Among all the models that were examined, CSIRO-Mk3.6.0 and IPSL-CM5AMR showed overall correlation greater than 0.4. IPSLCM5A-MR showed the best performance with overall $R^{2}$ greater than 0.4 for correlation with both the satellite sensors $\left(R_{\text {MISR }}^{2}=0.47 ; R_{\text {MODIS }}^{2}=0.40\right)$. Regional and seasonal dependence of the correlation between model and satellitederived AOD was observed. Models were observed to perform poorly over oceans and east coast of India; and comparatively better over land, especially over Thar desert and western India.

Seasonal variation observed in satellite-derived AOD was reproduced by all model groups. The magnitude of AOD was well reproduced by CSIRO-Mk3.6.0 and IPSL-CM5A-MR models; however, it was very low for other models. The variation of AOD with latitude was well reproduced by all the three model categories, with numerical differences, which got larger over the north of the Indo-Gangetic Basin. Correlation of selected models with MISR over various sub-regions showed that in general IPSL-CM5A-MR shows the best performance among all models even for different sub-regions also, except for southern India. Importance of biogeochemical cycle in the simulation process is also noticed. Results of this study would help in identifying the regions and seasons where an improvement in various models is required. This would result in better simulation of present-day global aerosol climatology. It will have further implications on the accuracy of studies on future climate.

\section{Data availability}

CMIP5 model aerosol data product is available from Centre for Environmental Data Archival (CEDC) incorporating BADC, NEODC, UKSSDC, SPARC and IPCC-DDC data centres (http://www.ceda.ac.uk). MISR Level 2 AOD data is obtained using Reverb Tool from Atmospheric Science 
Data Centre at the NASA Langley Research Centre. MODIS Level 3 AOD data is available from Level 1 and Atmosphere Archive and Distribution System (LAADS) (http://ladsweb. nascom.nasa.gov/). All data analyses are performed in Interactive Data Language (IDL) version 7.0 software.

Acknowledgements. We acknowledge the World Climate Research Programme's Working Group on Coupled Modelling, which is responsible for CMIP, and we thank the climate modelling groups (listed in Table 1 of this paper) for producing and making available their model output. For CMIP the US Department of Energy's Program for Climate Model Diagnosis and Intercomparison provides coordinating support and led development of software infrastructure in partnership with the Global Organization for Earth System Science Portals. We acknowledge the LPDAAC for providing the MODIS data used in this study. The MISR data were obtained from the NASA Langley Research Center Atmospheric Science Data Center. We thank the respective PIs of the climate modelling groups for providing necessary information about the models examined in this study. This work is supported by the Ministry of Earth Sciences, Government of India.

The topical editor, V. Kotroni, thanks the three anonymous referees for help in evaluating this paper.

\section{References}

Bentsen, M., Bethke, I., Debernard, J. B., Iversen, T., Kirkevåg, A., Seland, Ø., Drange, H., Roelandt, C., Seierstad, I. A., Hoose, C., and Kristjánsson, J. E.: The Norwegian Earth System Model, NorESM1-M -Part 1: Description and basic evaluation of the physical climate, Geosci. Model Dev., 6, 687-720, doi:10.5194/gmd-6-687-2013, 2013.

Bi, D., Dix, M., Marsland, S. J., O'Farrell, S., Rashid, H., Uotila, P., Hirst, A., Kowalczyk, E., Golebiewski, M., Sullivan, A., Yan, H., Hannah, N., Franklin, C., Sun, Z., Vohralik, P., Watterson, I., Zhou, X., Fiedler, R., Collier, M., Ma, Y., Noonan, J., Stevens, L., Uhe, P., Zhu, H., Griffies, S. M., Hill, R., Harris, C., and Puri, K.: The ACCESS coupled model: description, control climate and evaluation, Aust. Meteorol. Oceanogr. J., 63, 41-64, 2013.

Boucher, O., Randall D., Artaxo, P., Bretherton, C., Feingold, G., Forster, P., Kerminen, V.-M., Kondo, Y., Liao, H., Lohmann, U., Rasch, P., Satheesh, S., Sherwood, S., B., S., and Zhang, X.: Clouds and Aerosols. In: Climate Change 2013: The Physical Science Basis. Contribution of Working Group I to the Fifth Assessment Report of the Intergovernmental Panel on Climate Change, edited by: Stocker, T. F., Qin, D., Plattner, G.-K., Tignor, M., Allen, S. K., Boschung, J., Nauels, A., Xia, Y., Bex, V., and Midgley, P. M., Cambridge University Press, Cambridge, United Kingdom and New York, NY, USA, 2013.

Centre for Environmental Data Archival (CEDC): BADC, NEODC, UKSSDC, SPARC and IPCC-DDC data centres, available at: http://www.ceda.ac.uk, last access: 2013.

Cheng, T., Chen, H., Gu, X., Yu, T., Guo, J., and Guo, H.: The intercomparison of MODIS, MISR and GOCART aerosol products against AERONET data over China, J. Quant. Spectrosc. Ra., 113, 2135-2145, doi:10.1016/j.jqsrt.2012.06.016, 2012.
Choudhry, P., Misra, A., and Tripathi, S. N.: Study of MODIS derived AOD at three different locations in the Indo Gangetic Plain: Kanpur, Gandhi College and Nainital, Ann. Geophys., 30, 14791493, doi:10.5194/angeo-30-1479-2012, 2012.

Chu, D. A., Kaufman, Y. J., Ichoku, C., Remer, L. A., Tanré, D., and Holben, B. N.: Validation of MODIS aerosol optical depth retrieval over land, Geophys. Res. Lett., 29, 8007, doi:10.1029/2001GL013205, 2002.

Collins, W. J., Bellouin, N., Doutriaux-Boucher, M., Gedney, N., Halloran, P., Hinton, T., Hughes, J., Jones, C. D., Joshi, M., Liddicoat, S., Martin, G., O’Connor, F., Rae, J., Senior, C., Sitch, S., Totterdell, I., Wiltshire, A., and Woodward, S.: Development and evaluation of an Earth-System model - HadGEM2, Geosci. Model Dev., 4, 1051-1075, doi:10.5194/gmd-4-10512011, 2011.

Das, S. K., Jayaraman, A., and Misra, A.: Fog-induced variations in aerosol optical and physical properties over the Indo-Gangetic Basin and impact to aerosol radiative forcing, Ann. Geophys., 26, 1345-1354, doi:10.5194/angeo-26-1345-2008, 2008.

Desouza, N. D., Blaise, D., Kurchania, R., and Qureshi, M.: Dust emission from different soil types in the northwest and the IndoGangetic Plains of India, Atmósfera, 28, 251-260, 2015.

Devara, P., Saha, S., Raj, P. E., Sonbawne, S., Dani, K., Tiwari, Y., and Maheskumar, R.: A four-year climatology of total column tropical urban aerosol, ozone and water vapor distributions over Pune, India, Aerosol Air Qual. Res., 5, 103-114, 2005.

Dey, S., Tripathi, S. N., Singh, R. P., and Holben, B. N.: Influence of dust storms on the aerosol optical properties over the Indo-Gangetic basin, J. Geophys. Res., 109, D20211, doi:10.1029/2004JD004924, 2004.

Dey, S., Tripathi, S. N., Singh, R. P., and Holben, B. N.: Seasonal variability of the aerosol parameters over Kanpur, an urban site in Indo-Gangetic basin, Adv. Space Res., 36, 778-782, doi:10.1016/j.asr.2005.06.040, 2005.

Di Girolamo, L., Bond, T. C., Bramer, D., Diner, D. J., Fettinger, F., Kahn, R. A., Martonchik, J. V., Ramana, M. V., Ramanathan, V., and Rasch, P. J.: Analysis of Multi-angle Imaging SpectroRadiometer (MISR) aerosol optical depths over greater India during winter 2001-2004, Geophys. Res. Lett., 31, L23115, doi:10.1029/2004GL021273, 2004.

Donner, L. J., Wyman, B. L., Hemler, R. S., Horowitz, L. W., Ming, Y., Zhao, M., Golaz, J.-C., Ginoux, P., Lin, S.-J., Schwarzkopf, M. D., Austin, J., Alaka, G., Cooke, W. F., Delworth, T. L., Freidenreich, S. M., Gordon, C. T., Griffies, S. M., Held, I. M., Hurlin, W. J., Klein, S. A., Knutson, T. R., Langenhorst, A. R., Lee, H.-C., Lin, Y., Magi, B. I., Malyshev, S. L., Milly, P. C. D., Naik, V., Nath, M. J., Pincus, R., Ploshay, J. J., Ramaswamy, V., Seman, C. J., Shevliakova, E., Sirutis, J. J., Stern, W. F., Stouffer, R. J., Wilson, R. J., Winton, M., Wittenberg, A. T., and Zeng, F.: The dynamical core, physical parameterizations, and basic simulation characteristics of the atmospheric component AM3 of the GFDL global coupled model CM3, J. Climate, 24, 3484-3519, doi:10.1175/2011JCLI3955.1, 2011.

Dufresne, J.-L., Foujols, M.-A., Denvil, S., Caubel, A., Marti, O., Aumont, O., Balkanski, Y., Bekki, S., Bellenger, H., Benshila, R., Bony, S., Bopp, L., Braconnot, P., Brockmann, P., Cadule, P., Cheruy, F., Codron, F., Cozic, A., Cugnet, D., de Noblet, N., Duvel, J.-P., Ethé, C., Fairhead, L., Fichefet, T., Flavoni, S., Friedlingstein, P., Grandpeix, J.-Y., Guez, L., Guilyardi, E., 
Hauglustaine, D., Hourdin, F., Idelkadi, A., Ghattas, J., Joussaume, S., Kageyama, M., Krinner, G., Labetoulle, S., Lahellec, A., Lefebvre, M.-P., Lefevre, F., Levy, C., Li, Z. X., Lloyd, J., Lott, F., Madec, G., Mancip, M., Marchand, M., Masson, S., Meurdesoif, Y., Mignot, J., Musat, I., Parouty, S., Polcher, J., Rio, C., Schulz, M., Swingedouw, D., Szopa, S., Talandier, C., Terray, P., Viovy, N., and Vuichard, N.: Climate change projections using the IPSL-CM5 Earth System Model: from CMIP3 to CMIP5, Clim. Dyn., 40, 2123-2165, doi:10.1007/s00382-0121636-1, 2013.

Dumka, U. C., Tripathi, S. N., Misra, A., Giles, D. M., Eck, T. F., Sagar, R., and Holben, B. N.: Latitudinal variation of aerosol properties from Indo-Gangetic Plain to central Himalayan foothills during TIGERZ campaign, J. Geophys. Res., 119, 4750-4769, doi:10.1002/2013JD021040, 2014.

Dunne, J. P., John, J. G., Adcroft, A. J., Griffies, S. M., Hallberg, R. W., Shevliakova, E., Stouffer, R. J., Cooke, W., Dunne, K. A., Harrison, M. J., Krasting, J. P., Malyshev, S. L., Milly, P. C. D., Phillipps, P. J., Sentman, L. T., Samuels, B. L., Spelman, M. J., Winton, M., Wittenberg, A. T., and Zadeh, N.: GFDL's ESM2 Global Coupled Climate-Carbon Earth System Models. Part I: Physical Formulation and Baseline Simulation Characteristics, J. Climate, 25, 6646-6665, doi:10.1175/JCLI-D-11-00560.1, 2012.

Ganguly, D., Jayaraman, A., and Gadhavi, H.: Physical and optical properties of aerosols over an urban location in western India: Seasonal variabilities, J. Geophys. Res., 111, D24206, doi:10.1029/2006JD007392, 2006.

Ganguly, D., Ginoux, P., Ramaswamy, V., Winker, D. M., Holben, B. N., and Tripathi, S. N.: Retrieving the composition and concentration of aerosols over the Indo-Gangetic basin using CALIOP and AERONET data, Geophys. Res. Lett., 36, L13806, doi:10.1029/2009GL038315, 2009.

Gatebe, C. K., King, M. D., Tsay, S.-C., Ji, Q., Arnold, G. T., and Li, J. Y.: Sensitivity of off-nadir zenith angles to correlation between visible and near-infrared reflectance for use in remote sensing of aerosol over land, IEEE Trans. Geosci. Remote Sens., 39, 805819, doi:10.1109/36.917901, 2001.

Gautam, R., Hsu, N. C., and Lau, K.-M.: Premonsoon aerosol characterization and radiative effects over the Indo-Gangetic Plains: Implications for regional climate warming, J. Geophys. Res., 115, D17208, doi:10.1029/2010JD013819, 2010.

Ghan, S. J. and Schwartz, S. E.: Aerosol properties and processes, B. Am. Meteorol. Soc., 88, 1059-1083, doi:10.1175/BAMS-887-1059, 2007.

Ginoux, P., Chin, M., Tegen, I., Prospero, J. M., Holben, B., Dubovik, O., and Lin, S.-J.: Sources and distributions of dust aerosols simulated with the GOCART model, J. Geophys. Res., 106, 20255-20273, 2001.

Gogoi, M. M., Pathak, B., Moorthy, K. K., Bhuyan, P. K., Babu, S. S., Bhuyan, K., and Kalita, G.: Multi-year investigations of near surface and columnar aerosols over Dibrugarh, northeastern location of India: Heterogeneity in source impacts, Atmos. Environ., 45, 1714-1724, doi:10.1016/j.atmosenv.2010.12.056, 2011.

Iversen, T., Bentsen, M., Bethke, I., Debernard, J. B., Kirkevåg, A., Seland, Ø., Drange, H., Kristjansson, J. E., Medhaug, I., Sand, M., and Seierstad, I. A.: The Norwegian Earth System Model, NorESM1-M - Part 2: Climate response and scenario projections, Geosci. Model Dev., 6, 389-415, doi:10.5194/gmd-6-3892013, 2013.
Jethva, H., Satheesh, S. K., and Srinivasan, J.: Assessment of second-generation MODIS aerosol retrieval (Collection 005) at Kanpur, India, Geophys. Res. Lett., 34, L19802, doi:10.1029/2007GL029647, 2007a.

Jethva, H., Satheesh, S. K., and Srinivasan, J.: Evaluation of Moderate-Resolution Imaging Spectroradiometer (MODIS) Collection 004 (C004) aerosol retrievals at Kanpur, Indo-Gangetic Basin, J. Geophys. Res., 112, D14216, doi:10.1029/2006JD007929, 2007b.

Kahn, R. A., Gaitley, B. J., Martonchik, J. V., Diner, D. J., Crean, K. A., and Holben, B.: Multiangle Imaging Spectroradiometer (MISR) global aerosol optical depth validation based on 2 years of coincident Aerosol Robotic Network (AERONET) observations, J. Geophys. Res., 110, D10S04, doi:10.1029/2004JD004706, 2005.

Kaskaoutis, D. G., Badarinath, K. V. S., Kumar Kharol, S., Rani Sharma, A., and Kambezidis, H. D.: Variations in the aerosol optical properties and types over the tropical urban site of Hyderabad, India, J. Geophys. Res., 114, D22204, doi:10.1029/2009JD012423, 2009.

Kaufman, Y. J., Tanré, D., Remer, L. A., Vermote, E. F., Chu, A., and Holben, B. N.: Operational remote sensing of tropospheric aerosol over land from EOS moderate resolution imaging spectroradiometer, J. Geophys. Res., 102, 17051, doi:10.1029/96JD03988, 1997.

King, M. D., Kaufman, Y. J., Tanré, D., and Nakajima, T.: Remote Sensing of Tropospheric Aerosols from Space: Past, Present, and Future., B. Am. Meteorol. Soc., 80, 2229-2260, doi:10.1175/1520-0477(1999)080<2229:RSOTAF>2.0.CO;2, 1999.

Krishna Moorthy, K., Suresh Babu, S., and Satheesh, S. K.: Temporal heterogeneity in aerosol characteristics and the resulting radiative impact at a tropical coastal station - Part 1: Microphysical and optical properties, Ann. Geophys., 25, 2293-2308, doi:10.5194/angeo-25-2293-2007, 2007.

Krishna Moorthy, K., Suresh Babu, S., Manoj, M. R., and Satheesh, S. K.: Buildup of aerosols over the Indian Region, Geophys. Res. Lett., 40, 1011-1014, doi:10.1002/grl.50165, 2013.

Kumar, R., Barth, M. C., Madronich, S., Naja, M., Carmichael, G. R., Pfister, G. G., Knote, C., Brasseur, G. P., Ojha, N., and Sarangi, T.: Effects of dust aerosols on tropospheric chemistry during a typical pre-monsoon season dust storm in northern India, Atmos. Chem. Phys., 14, 6813-6834, doi:10.5194/acp-146813-2014, 2014.

Kumar, S., Devara, P. C. S., and Manoj, M. G.: Multisite characterization of tropical aerosols: Implications for regional radiative forcing, Atmos. Res., 106, 71-85, doi:10.1016/j.atmosres.2011.11.009, 2012.

Kuniyal, J. C., Thakur, A., Thakur, H. K., Sharma, S., Pant, P., Rawat, P. S., and Moorthy, K. K.: Aerosol optical depths at Mohal-Kullu in the northwestern Indian Himalayan high altitude station during ICARB, J. Earth Sys. Sci., 118, 41-48, doi:10.1007/s12040-009-0004-y, 2009.

Level 1 and Atmosphere Archive and Distribution System (LAADS): MODIS Level 3 AOD data, available at: http:// ladsweb.nascom.nasa.gov/, last access: 2013.

Levy, R. C., Remer, L. A., and Kaufman, Y. J.: Effects of neglecting polarization on the MODIS aerosol retrieval over land, IEEE Trans. Geosci. Remote S., 42, 2576-2583, 2004. 
Levy, R. C., Remer, L. A., Kleidman, R. G., Mattoo, S., Ichoku, C., Kahn, R., and Eck, T. F.: Global evaluation of the Collection 5 MODIS dark-target aerosol products over land, Atmos. Chem. Phys., 10, 10399-10420, doi:10.5194/acp-10-10399-2010, 2010.

Liu, Y., Sarnat, J. A., Coull, B. A., Koutrakis, P., and Jacob, D. J.: Validation of Multiangle Imaging Spectroradiometer (MISR) aerosol optical thickness measurements using Aerosol Robotic Network (AERONET) observations over the contiguous United States, J. Geophys. Res., 109, D06205, doi:10.1029/2003JD003981, 2004.

Lodhi, N. K., Beegum, S. N., Singh, S., and Kumar, K.: Aerosol climatology at Delhi in the western Indo-Gangetic Plain: Microphysics, long-term trends, and source strengths, J. Geophys. Res., 118, 1361-1375, doi:10.1002/jgrd.50165, 2013.

Meehl, G. A., Washington, W. M., Arblaster, J. M., Hu, A., Teng, H., Kay, J. E., Gettelman, A., Lawrence, D. M., Sanderson, B. M., and Strand, W. G.: Climate change projections in CESM1 (CAM5) compared to CCSM4, J. Climate, 26, 6287-6308, doi:10.1175/JCLI-D-12-00572.1, 2013.

Mehta, M.: A study of aerosol optical depth variations over the Indian region using thirteen years (2001-2013) of MODIS and MISR Level 3 data, Atmos. Environ., 109, 161-170, 2015.

Misra, A., Jayaraman, A., and Ganguly, D.: Validation of MODIS derived aerosol optical depth over Western India, J. Geophys. Res., 113, D04203, doi:10.1029/2007JD009075, 2008.

Misra, A., Gaur, A., Bhattu, D., Ghosh, S., Dwivedi, A. K., Dalai, R., Paul, D., Gupta, T., Tare, V., Mishra, S. K., Singh, S., and Tripathi, S. N.: An overview of the physico-chemical characteristics of dust at Kanpur in the central Indo-Gangetic basin, Atmos. Environ., 97, 386-396, doi:10.1016/j.atmosenv.2014.08.043, 2014a.

Misra, A., Jayaraman, A., and Ganguly, D.: Validation of Version 5.1 MODIS Aerosol Optical Depth (Deep Blue Algorithm and Dark Target Approach) over a Semi-Arid Location in Western India, Aerosol Air Qual. Res., doi:10.4209/aaqr.2014.01.0004, 2014b.

Naseema Beegum, S., Krishna Moorthy, K., Gogoi, M. M., Suresh Babu, S., and Pandey, S. K.: Multi-year investigations of aerosols from an island station, Port Blair, in the Bay of Bengal: climatology and source impacts, Ann. Geophys., 30, 1113-1127, doi:10.5194/angeo-30-1113-2012, 2012.

Niranjan, K., Spandana, B., Anjana Devi, T., Sreekanth, V., and Madhavan, B. L.: Measurements of aerosol intensive properties over Visakhapatnam, India for 2007, Ann. Geophys., 29, 973985, doi:10.5194/angeo-29-973-2011, 2011.

Pan, X., Chin, M., Gautam, R., Bian, H., Kim, D., Colarco, P. R., Diehl, T. L., Takemura, T., Pozzoli, L., Tsigaridis, K., Bauer, S., and Bellouin, N.: A multi-model evaluation of aerosols over South Asia: common problems and possible causes, Atmos. Chem. Phys., 15, 5903-5928, doi:10.5194/acp-15-5903-2015, 2015.

Pathak, B., Kalita, G., Bhuyan, K., Bhuyan, P. K., and Moorthy, K. K.: Aerosol temporal characteristics and its impact on shortwave radiative forcing at a location in the northeast of India, J. Geophys. Res., 115, D19204, doi:10.1029/2009JD013462, 2010.

Prasad, A. K. and Singh, R. P.: Comparison of MISR-MODIS aerosol optical depth over the Indo-Gangetic basin during the winter and summer seasons (2000-2005), Rem. Sens. Environ., 107, 109-119, 2007.
Ramachandran, S., Srivastava, R., Kedia, S., and Rajesh, T.: Contribution of natural and anthropogenic aerosols to optical properties and radiative effects over an urban location, Environ. Res. Lett., 7, 034028, doi:10.1088/1748-9326/7/3/034028, 2012.

Remer, L. A., Wald, A. E., and Kaufman, Y. J.: Angular and seasonal variation of spectral surface reflectance ratios: implications for the remote sensing of aerosol over land, IEEE Trans. Geosci. Remote S., 39, 275-283, doi:10.1109/36.905235, 2001.

Rotstayn, L. D., Collier, M. A., Dix, M. R., Feng, Y., Gordon, H. B., O'Farrell, S. P., Smith, I. N., and Syktus, J.: Improved simulation of Australian climate and ENSO-related rainfall variability in a global climate model with an interactive aerosol treatment International Journal of Climatology, Wiley Online Library, 30, 1067-1088, doi:10.1002/joc.1952, 2010.

Sagar, R., Kumar, B., Dumka, U. C., Moorthy, K. K., and Pant, P.: Characteristics of aerosol spectral optical depths over Manora Peak: A high-altitude station in the central Himalayas, J. Geophys. Res., 109, D06207, doi:10.1029/2003JD003954, 2004.

Sakamoto, T., Komuro, Y., Nishimura, T., Ishii, M., Tatebe, H., Shiogama, H., Hasegawa, A., Toyoda, T., Mori, M., Suzuki, T., Imada, Y., Nozawa, T., Takata, K., Mochizuki, T., Ogochi, K., Emori, S., Hasumi, H., and Kimoto M.: MIROC4h-a new highresolution atmosphere-ocean coupled general circulation model, J. Meteorol. Soc. Jpn., 90, 325-359, doi:10.2151/jmsj.2012-301, 2012.

Sanap, S., Ayantika, D., Pandithurai, G., and Niranjan, K.: Assessment of the aerosol distribution over Indian subcontinent in CMIP5 models, Atmos. Environ., 87, 123-137, 2014.

Satheesh, S., Vinoj, V., and Krishnamoorthy, K.: Assessment of aerosol radiative impact over oceanic regions adjacent to Indian subcontinent using Multisatellite analysis, Advances in Meteorology, 2010, 139186, doi:10.1155/2010/139186, 2010.

Schmidt, G. A., Kelley, M., Nazarenko, L., Ruedy, R., Russell, G. L., Aleinov, I., Bauer, M., Bauer, S. E., Bhat, M. K., Bleck, R., Canuto, V., Chen, Y.-H., Cheng, Y., Clune, T. L., Del Genio, A., de Fainchtein, R., Faluvegi, G., Hansen, J. E., Healy, R. J., Kiang, N. Y., Koch, D., Lacis, A. A., LeGrande, A. N., Lerner, J., Lo, K. K., Matthews, E. E., Menon, S., Miller, R. L., Oinas, V., Oloso, A. O., Perlwitz, J. P., Puma, M. J., Putman, W. M., Rind, D., Romanou, A., Sato, M., Shindell, D. T., Sun, S., Syed, R. A., Tausnev, N., Tsigaridis, K., Unger, N., Voulgarakis, A., Yao, M.S., and Zhang, J.: Configuration and assessment of the GISS ModelE2 contributions to the CMIP5 archive, J. Adv. Model. Earth Syst., 6, 141-184, doi:10.1002/2013MS000265, 2014.

Shindell, D. T., Lamarque, J.-F., Schulz, M., Flanner, M., Jiao, C., Chin, M., Young, P. J., Lee, Y. H., Rotstayn, L., Mahowald, N., Milly, G., Faluvegi, G., Balkanski, Y., Collins, W. J., Conley, A. J., Dalsoren, S., Easter, R., Ghan, S., Horowitz, L., Liu, X., Myhre, G., Nagashima, T., Naik, V., Rumbold, S. T., Skeie, R., Sudo, K., Szopa, S., Takemura, T., Voulgarakis, A., Yoon, J.-H., and Lo, F.: Radiative forcing in the ACCMIP historical and future climate simulations, Atmos. Chem. Phys., 13, 2939-2974, doi:10.5194/acp-13-2939-2013, 2013.

Srivastava, A., Devara, P., Rao, Y. J., Bhavanikumar, Y., and Rao, D.: Aerosol optical depth, ozone and water vapor measurements over Gadanki, a tropical station in peninsular India, Aerosol Air Qual. Res., 8, 459-476, 2008.

Srivastava, A. K., Tiwari, S., Devara, P. C. S., Bisht, D. S., Srivastava, M. K., Tripathi, S. N., Goloub, P., and Holben, B. N.: Pre- 
monsoon aerosol characteristics over the Indo-Gangetic Basin: implications to climatic impact, Ann. Geophys., 29, 789-804, doi:10.5194/angeo-29-789-2011, 2011.

Tanré, D., Kaufman, Y. J., Herman, M., and Mattoo, S.: Remote sensing of aerosol properties over oceans using the MODIS/EOS spectral radiances, J. Geophys. Res., 102, 16971, doi:10.1029/96JD03437, 1997.

Tare, V., Tripathi, S. N., Chinnam, N., Srivastava, A. K., Dey, S., Manar, M., Kanawade, V. P., Agarwal, A., Kishore, S., Lal, R. B., and Sharma, M.: Measurements of atmospheric parameters during Indian Space Research Organization Geosphere Biosphere Program Land Campaign II at a typical location in the Ganga Basin: 2. Chemical properties, J. Geophys. Res., 111, D23210, doi:10.1029/2006JD007279, 2006.

Taylor, K. E., Stouffer, R. J., and Meehl, G. A.: An overview of CMIP5 and the experiment design, B. Am. Meteorol. Soc., 93, 485-498, 2012.

Tjiputra, J. F., Roelandt, C., Bentsen, M., Lawrence, D. M., Lorentzen, T., Schwinger, J., Seland, Ø., and Heinze, C.: Evaluation of the carbon cycle components in the Norwegian Earth System Model (NorESM), Geosci. Model Dev., 6, 301-325, doi:10.5194/gmd-6-301-2013, 2013.

Tripathi, S. N., Dey, S., Chandel, A., Srivastava, S., Singh, R. P., and Holben, B. N.: Comparison of MODIS and AERONET derived aerosol optical depth over the Ganga Basin, India, Ann. Geophys., 23, 1093-1101, doi:10.5194/angeo-23-1093-2005, 2005.

Tripathi, S. N., Tare, V., Chinnam, N., Srivastava, A. K., Dey, S., Agarwal, A., Kishore, S., Lal, R. B., Manar, M., Kanwade, V. P., Chauhan, S. S. S., Sharma, M., Reddy, R. R., Gopal, K. R., Narasimhulu, K., Reddy, L. S. S., Gupta, S., and Lal, S.: Measurements of atmospheric parameters during Indian Space Research Organization Geosphere Biosphere Programme Land Campaign II at a typical location in the Ganga basin: 1. Physical and optical properties, J. Geophys. Res., 111, D23209, doi:10.1029/2006JD007278, 2006.
Verma, S., Venkataraman, C., and Boucher, O.: Attribution of aerosol radiative forcing over India during the winter monsoon to emissions from source categories and geographical regions, Atmos. Environ., 45, 4398-4407, doi:10.1016/j.atmosenv.2011.05.048, 2011.

Verma, S., Bhanja, S., Pani, S., and Misra, A.: Aerosol optical and physical properties during winter monsoon pollution transport in an urban environment, Environ. Sci. Pollut. R., 21, 4977-4994, 2014.

Vinoj, V., Satheesh, S. K., and Moorthy, K. K.: Aerosol characteristics at a remote island: Minicoy in southern Arabian Sea, J. Earth Syst. Sci., 117, 389-397, doi:10.1007/s12040-008-0017-y, 2008.

Vinoj, V., Satheesh, S., and Krishna Moorthy, K.: Aerosol characteristics at a continental urban station in southern India, International Journal of Environment and Waste Management, 4, 256266, 2009.

Watanabe, M., Suzuki, T., O'ishi, R., Komuro, Y., Watanabe, S., Emori, S., Takemura, T., Chikira, M., Ogura, T., Sekiguchi, M., Takata, K., Yamazaki, D., Yokohata, T., Nozawa, T., Hasumi, H., Tatebe, H., and Kimoto, M.: Improved climate simulation by MIROC5: mean states, variability, and climate sensitivity, J. Climate, 23, 6312-6335, 2010.

Wong, M. S., Shahzad, M. I., Nichol, J. E., Lee, K. H., and Chan, P. W.: Validation of MODIS, MISR, OMI, and CALIPSO aerosol optical thickness using ground-based sunphotometers in Hong Kong, Int. J. Remote Sens., 34, 897-918, doi:10.1080/01431161.2012.720739, 2013.

Yukimoto, S., Adachi, Y., Hosaka, M., Sakami, T., Yoshimura, H., Hirabara, M., Tanaka, T. Y., Shindo, E., Tsujino, H., Deushi, M., Mizuta, R., Yabu, S., Obata, A., Nakano, H., Koshiro, T., Ose, T., and Kitoh, A.: A new global climate model of the Meteorological Research Institute: MRI-CGCM3 - model description and basic performance, J. Meteorol. Soc. Jpn., 90, 23-64, doi:10. 2151/jm sj.2012-A 02, 2012. 